\title{
WATER ENVIRONMENTS IN THE SOUTHERN DELTA OF MYANMAR DURING THE RAINY SEASON
}

\author{
Makiko SENDA1, 2, 3, Kay Thwe HLAING ${ }^{4}$, Kunihide MIYAOKA ${ }^{5}$, \\ Shigeko HARUYAMA ${ }^{6}$ and Yasuhisa $\mathrm{KUZUHA}^{7}$ \\ ${ }^{1}$ Member of JSCE, Lecturer, Faculty of Health Science, Kyoto Koka Women's University and Kyoto Koka Women's \\ College (38, Nishikyougokukadono-cho, Ukyo-ku, Kyoto City, Kyoto 615-0882, Japan) \\ E-mail: m-senda@mail.koka.ac.jp \\ ${ }^{2}$ Lecturer, Faculty of Management, Osaka Seikei University and Osaka Seikei College \\ (3-10-62, Aikawa, Higashiyodogawa-ku, Osaka City, Osaka 533-0007, Japan) \\ E-mail: senda@osaka-seikei.ac.jp \\ ${ }^{3}$ Lecturer, Faculty of Human Development and Education, Kobe Shinwa Women's University \\ (7-13-1, Suzurandaikitamachi, Kita-ku, Kobe City, Hyogo 651-1111, Japan) \\ ${ }^{4}$ Nonmember of JSCE, Researcher, Graduate School of Bioresources, Mie University \\ (1577 Kurimamachiya-cho, Tsu City, Mie 514-8507, Japan) \\ E-mail: kthlaing@gmail.com \\ ${ }^{5}$ Nonmember of JSCE, Professor, Faculty of Education, Mie University \\ (1577 Kurimamachiya-cho, Tsu City, Mie 514-8507, Japan) \\ E-mail: miyaoka@edu.mie-u.ac.jp \\ ${ }^{6}$ Nonmember of JSCE, Professor, Graduate School of Bioresources, Mie University \\ (1577 Kurimamachiya-cho, Tsu City, Mie 514-8507, Japan) \\ E-mail: haruyama@bio.mie-u.ac.jp \\ ${ }^{7}$ Fellow of JSCE, Professor, Graduate School of Bioresources, Mie University \\ (1577 Kurimamachiya-cho, Tsu City, Mie 514-8507, Japan) \\ E-mail: kuzuha@bio.mie-u.ac.jp
}

\begin{abstract}
Some diseases in Myanmar during the rainy season are related to the water environment and the water quality. In order to contribute to ensuring safe water supply, we collected and analyzed water samples in Myanmar in September 2011. Early research had already reported that coliform and E. Coli were detected in all the survey areas. We examined the water quality, especially chemical components harmful for health, and classified the sample waters into water quality-types in order to identify the sources and contamination. We obtained the following results: (1) Some tube well, dug well, and filtered waters were estimated to be contaminated and unsuitable for drinking and domestic water. (2) Waters at elevation less than about $10 \mathrm{~m}$ were more likely to be polluted. (3) The chemical components beyond the drinking water guideline values of World Health Organization (WHO) for health were $\mathrm{NO}_{2}{ }^{-}, \mathrm{NO}_{3}^{-}, \mathrm{Pb}^{2+}$, and $\mathrm{Mn}^{2+}$. (4) For the taps with longer direct distance from the pumping station and lower elevation, there were several cases in which the tube well water geographically close to the tap intruded into the tap of filtered water. Then, we suggested some recommendations for water treatment based on WHO guidelines, and we also suggested the desirable improvements to the water supply systems. The first potential approach to treatment of drinking water supplies is to dilute the contaminated water with a low-contaminated source (e.g., high-elevation reservoirs). The desirable improvement to the water supply systems are as follows: (a) piping routes from reservoir to user places should be maintained as sanitary and clean, and (b) tube well water systems should be improved to prevent the intrusion of contaminants.
\end{abstract}

Key Words : Myanmar delta, water environment, hydrochemistry, rainy season, drinking water, domestic water

\section{INTRODUCTION}

Water plays an important role in our body activity and is indispensable to our life. Poor water quality continues to pose a major threat to human health. Diarrheal diseases alone account for an estimated 
Table 1 Diseases in Myanmar caused by drinking water and domestic water that are not hygienic ${ }^{53}$-10).

\begin{tabular}{c|c|c}
\hline Season & Diseases and symptoms prevalent in the season & Disease prevalent throughout the year \\
\hline Hot season & - & $\begin{array}{c}\text { Diarrhea } \\
\text { Malaria }\end{array}$ \\
Rainy season & Waterborne diseases \\
Food poisoning & $\begin{array}{c}\text { Incidence of dengue } \\
\text { Eye infections } \\
\text { Skin diseases }\end{array}$ \\
\hline Dry season & - & dingen \\
\hline
\end{tabular}

4.1\% of the total Disability-Adjusted Life Years (DALY) global burden of disease and are responsible for the deaths of 1.8 million people every year ${ }^{1)}$. An estimated $88 \%$ of that burden is attributable to unsafe water supply, and poor sanitation and hygiene. The deaths are mostly concentrated among children in developing countries. In Myanmar, water-, sanitation- and hygiene-attributable deaths per 100,000 children under five years old were 378 in 2004²).

In general, when public sanitation circumstances are such that drinking and domestic water are polluted, severe health damage can occur. For example, groundwater, including $\mathrm{NO}_{3}{ }^{-}$, might cause methemoglobin symptoms ${ }^{3), 4)}$. In addition, malaria, water system infectious disease, waterborne diseases, digestive organ diseases, food poisoning, and typhoid fever can easily occur.

In most areas of Myanmar, groundwater, lake water, and river water are used for both drinking and domestic water. The conditions of the hygiene environment such as waterworks or the sewers are not so good. Health damage caused by polluted water becomes a social problem, thus immediate measures are demanded. Alimentary disease, food poisoning, and typhoid fever including water system-related infectious diseases occur more in the rainy season (May-October) than in the dry season ${ }^{5-10)}$ (Table 1). According to Akaishi et al., (2004) $)^{6}$, coliform and E. Coli were detected in all the survey areas.

In Myanmar, the threat of floods usually occurs in three waves each year: June, August, and late September to October with the greatest danger happening in August as peak monsoon rains occur. Floods lead to loss of life and property, damage to critical infrastructure, economic loss, and health-related problems such as outbreak of waterborne diseases when lakes, ponds, and reservoirs become contaminated. The country receives practically all its rainfall between mid-May and October, the rainy season, during which time floods and landslides are common. During 1910-2000, 12 major floods occurred. The Ayeyarwady River Basin alone, the largest in the country, covers $404,200 \mathrm{~km}^{2}$ in the country. Over 2 million people are exposed to flood hazards in Myanmar every year. However, annual riverine floods are regarded as a natural phenomenon in the river basins that help clean the farm lands and replenish the ground with nutrients carried from upriver ${ }^{11)}$.

Regarding water quality in Myanmar, it is important to assess the present circumstances of the water environment. We chose September and investigated the data, because it was the month for disease outbreak in the rainy season and it was a country into which foreigners were unable to enter for frequent investigations

We chose land cover and elevation as geographical information that could be read directly. The former is regarded as an index of load on area. The latter is regarded as an index of material transfer or transport potential, because material is transported by water from higher position to lower position.

Total coliform had already been surveyed and reported in the above early research ${ }^{6)}$, but little information on chemical hazards has been reported. From the viewpoint of the effect of chemical components on water quality, we selected EC (electrical conductivity) and material concentration such as $\mathrm{NO}_{3}{ }^{-}$as an index to evaluate water quality. High EC indicates artificial contaminants, such as domestic drain water, and $\mathrm{NO}_{3}{ }^{-}$is generated by oxidation of ammonia contained in fertilizer and excrement of livestock. If a good correlation is obtained between geographical information and water quality, it would be easier to evaluate a wide area of the Myanmar delta. Understanding the fluctuation tendency of water quality over a wide area is useful for use, control, and development of water resources.

We had collected water samples in January and September 2010. After our measurements, we performed principal component analysis and cluster analysis. Consequently, the concentrations of $\mathrm{Cl}^{-}$, $\mathrm{NH}_{4}-\mathrm{N}$, and $\mathrm{NO}_{2}-\mathrm{N}$ were extremely high. Therefore, the water was not appropriate for drinking. By principal component analysis, we found that concentrations were very closely correlated among $\mathrm{NH}_{4}-\mathrm{N}, \mathrm{F}^{-}$, and $\mathrm{Cl}^{-}$. By cluster analysis, waters in these areas were divided into four groups. Furthermore, we found that the water quality of well water and tap water was worse than the quality of the water of river water and pond water ${ }^{12)}$.

In this study, based on these results, we focused attention to the wells (tube well and dug well) water, 
reservoir water, and filtered water. We collected the 36 samples in September 24-30, 2011. We examined the water quality (chemical hazards) by comparison with WHO guidelines, and discussed the relations between land cover, elevation, and water quality. We classified the type of water by Piper diagram. Then, we suggested the recommendations for water treatment.

\section{STUDY AREA AND METHODS}

\section{(1) Sampling points and elevation of the study area}

The Ayeyarwady delta, with approximately $50,400 \mathrm{~km}^{2}$ area, is used mainly for rice cultivation. The nearly 2,170 km-long Ayeyarwady River, Myanmar's longest river, flows into the Gulf of Martaban. Most of Myanmar's population live in the Ayeyarwady delta, located between the Rakhine and the Shan Plateau.

Fig. 1 presents the locations of the sampling points and elevation. We collected 36 samples ("tube well water," "dug well water," "reservoir water," and "filtered water") in September 24-30, 2011.

"Tube well water" is water from "tube well" obtained by driving a tube into the ground to a stratum that bears water. "Dug well water" is water of "dug well" obtained by digging holes in the ground using a shovel or backhoe. "Reservoir water" is water from reservoirs and lakes. "Filtered water" is water chlorinated after having filtered reservoir water at the pumping station.

We adopted one sample of "mineral water of the marketing product (bottled groundwater) (Sample No. M1)" used by wealthier consumers.

Samples of Site Nos. T1-T18 are "tube well water." Samples of Site Nos. D1-D3 are "dug well water."

Samples of Site Nos. R1-R6 are "reservoir water." Samples of No.R1 and R2 are water from the Gyobyu reservoir. A sample of No. R3 is water from the Phu Gyi reservoir. Samples of No. R4 are water from Lake Hlawga. As a result of interviews with the staff of the pumping station, sample of No. R5 was mixed water from four reservoirs (the Gyobyu reservoir, the Phu Gyi reservoir, Lake Hlawga, and the Ngamoyeik reservoir), and sample of No. R6 was mixed water from two reservoirs (the Gyobyu reservoir and Lake Hlawga).

Samples of site Nos. F1-F9 are "filtered water." The staff of the pumping station explained that the sample of No. F1 was filtered and chlorinated water of No. R5, and the sample of F2 was filtered and

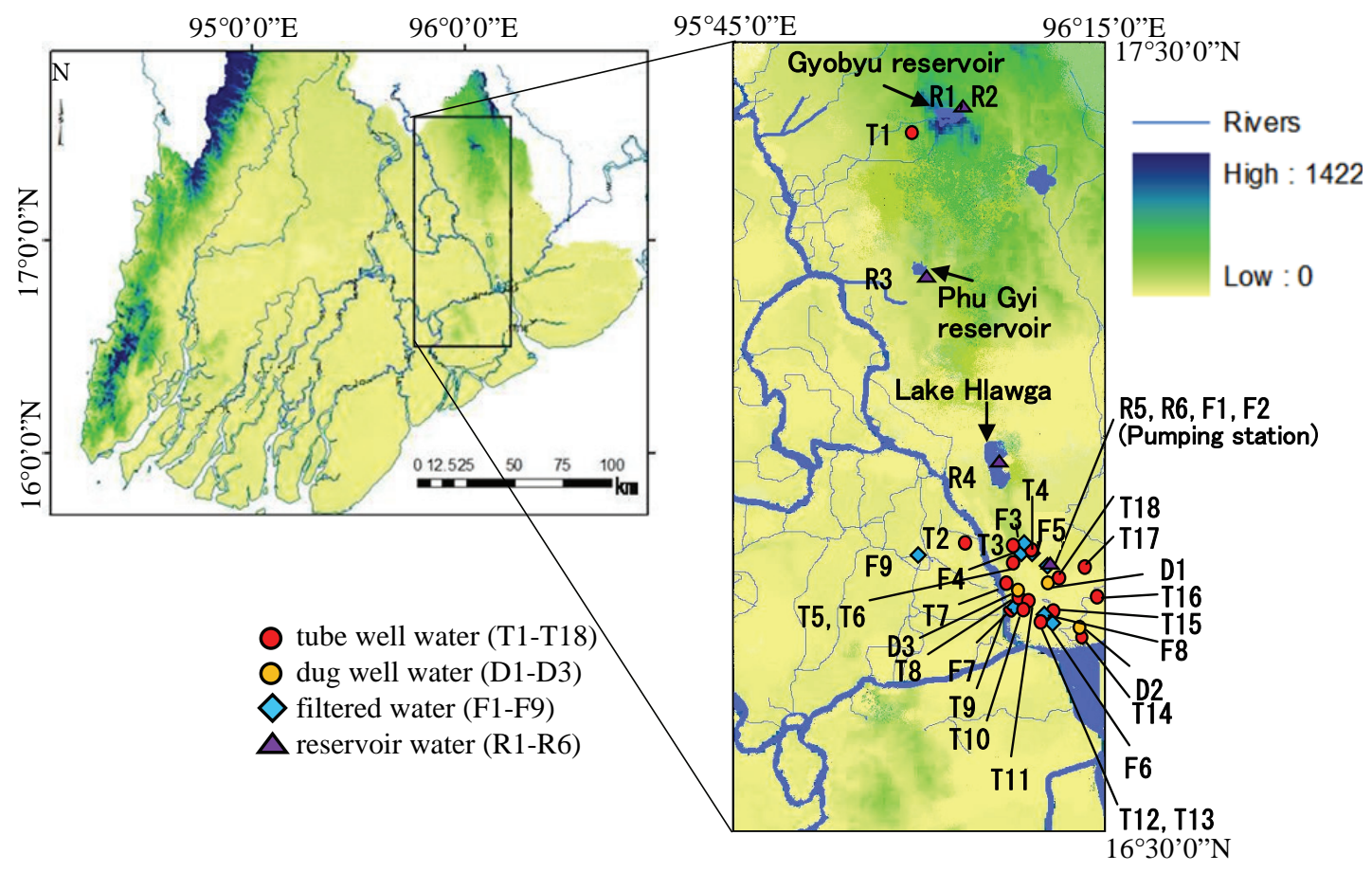

Fig.1 Sampling points and elevation of the study area. R1-R6: reservoir water; T1-T8: tube well water; D1-D3: dug well water, F1-F9: filtered water. 


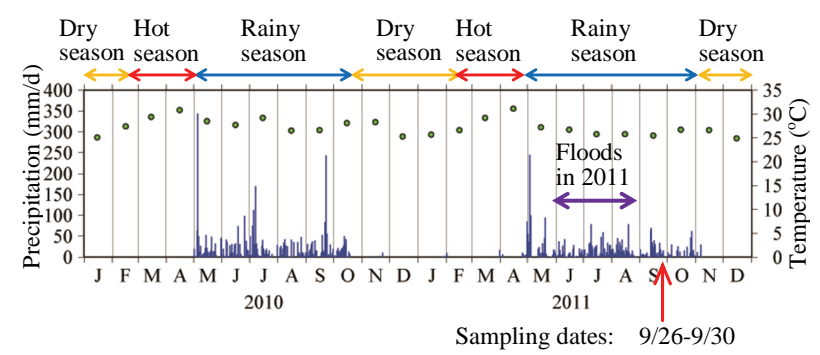

Fig.2 Atmospheric temperature, precipitation, classification of the seasons, and flood period in Yangon City, (Mingalardon) Myanmar. Floods occur every year, but flooding in 2010 was not severe in Myanmar. Floods occurred from June 1 to the end of August 2011. There were no floodings during the sampling periods.

—, Precipitation amount; $\bigcirc$, Temperature

chlorinated water of No. R6.

Generally, the water service in Japan is supplied by pipe routes from pumping station to houses. The situation in Myanmar is much different now. A lot of improvements seem to be necessary to better manage water services in Myanmar ${ }^{13)}$.

\section{(2) Meteorological data}

Fig. 2 shows meteorological data from January 2010 to December 2011 at Mingalardon in Yangon City ${ }^{14)}$. In September 2011, the average daily atmospheric temperature was $25.5^{\circ} \mathrm{C}$, and the average daily precipitation was $14.8 \mathrm{~mm}$. The total daily precipitation was $443 \mathrm{~mm}$.

Floods occur every year but flooding in 2010 was not severe. Flooding occurred from June 1 to the end of August 2011. The highest flood in 2011 occurred during August 18 to August 28. There were no floodings during the sampling periods.

\section{(3) Sampling methods and analytical techniques}

Electric conductivity (EC), $\mathrm{pH}$, and water temperature were measured in the field using portable electronic instruments. We measured latitude, longitude, and elevation of site by Global Positioning System (GPS) (Garmin Ltd., GPSMAP60CSx, Altimeter: Accuracy; +/-10feet (3.048m), resolution; 1 ft. $(0.3048 m))^{15)}$.

After pouring the water collected into the sample bottle, and bringing them by airplane in a low temperature state to the greatest degree possible, we measured them after filtering with a membrane filter in the laboratory in Japan.

The $\mathrm{F}^{-}, \mathrm{Cl}^{-}, \mathrm{NO}_{2}{ }^{-}, \mathrm{Br}^{-}, \mathrm{NO}_{3}{ }^{-}, \mathrm{PO}_{4}{ }^{3-}, \mathrm{SO}_{4}{ }^{2-}, \mathrm{Li}^{+}, \mathrm{Na}^{+}$, $\mathrm{NH}_{4}^{+}, \mathrm{K}^{+}, \mathrm{Mg}^{2+}$, and $\mathrm{Ca}^{2+}$ were analyzed using ion chromatography (Prominence HIC-SP/NS; Shimadzu Corp., Japan), in anion analysis using suppressor method (column: Shim-Pack IC-SA2) in positive ion analysis by non-suppressor method (column: Shim-Pack IC-C4).

The $\mathrm{Al}^{3+}, \mathrm{Ba}^{2+}, \mathrm{Cu}^{2+}, \mathrm{Fe}^{2+}, \mathrm{Mn}^{2+}, \mathrm{Ni}^{2+}, \mathrm{Pb}^{2+}$, and $\mathrm{Zn}^{2+}$ were analyzed using an inductively coupled plasma optical emission spectrometer (ICP-OES; SII Nano Technology Inc., Japan).

The $\mathrm{HCO}_{3}{ }^{-}$concentration was determined by titration with standard sulfuric acid $0.01 \mathrm{M}$.

\section{RESULTS AND DISCUSSION}

\section{(1) Characteristics of water}

Table 2 presents a summary of the places of sampling, use, elevation, EC, $\mathrm{pH}$, temperature of the water, soil type ${ }^{16)}$, and land cover ${ }^{17)}$. It was found that EC and water quality were not correlated with soil type and land cover.

Fig. 3 shows the water quality of reservoir water (R1-R6), filtered water (F1-F9), tube well water (T1-T18), dug well water (D1-D3), and mineral water (bottled groundwater) (M1). Fig. 4 shows the chemical hazards ${ }^{18)}\left(\mathrm{NO}_{2}^{-}, \mathrm{NO}_{3}^{-}, \mathrm{Pb}^{2+}\right.$, and $\left.\mathrm{Mn}^{2+}\right)$ in drinking water.

As shown in Table 2, regarding EC, the average, minimum (F3), and maximum (T12) were 38.73, 5.01 , and $467.00 \mathrm{mS} / \mathrm{m}$, respectively. Regarding $\mathrm{pH}$, the average, minimum (T12), and maximum (T2) were $6.75,5.10$, and 9.80, respectively. Regarding temperature, the average, minimum (M1), and maximum (R3) were 27.9, 23.9, and $30.0{ }^{\circ} \mathrm{C}$ respectively.

Fig.3 shows that the concentrations were widely varied because of the variation in samples and the areas from which they were collected. Compared to the reservoir waters, filtered waters contained more $\mathrm{Fe}^{2+}$. The $\mathrm{Fe}^{2+}$ content results could reflect the possibility of dissolution through pipe routes from reservoirs to user locations. The pipe is made of iron $^{19)}$. And, in the filtered waters, $\mathrm{Br}^{-}, \mathrm{PO}_{4}^{3-}, \mathrm{Li}^{+}, \mathrm{Ba}^{2+}, \mathrm{Cu}^{2+}$, $\mathrm{Mn}^{2+}, \mathrm{Ni}^{2+}$, and $\mathrm{Zn}^{2+}$ were found, which were not found in the reservoir waters. Therefore, this case could be regarded as contamination through piping routes. However, concentration values of these contaminations were lower than those of the WHO guideline values on human health. The $\mathrm{NH}_{4}{ }^{+}$of filtered waters is discussed in Section (3) b).

The concentrations of various ions in well (tube well and dug well) water were higher than those of filtered water (Fig. 3). Particularly, in well water, concentrations of $\mathrm{NO}_{2}^{-}, \mathrm{NO}_{3}^{-}, \mathrm{Mn}^{2+}$, and $\mathrm{Pb}^{2+}$ were present more than those in the WHO guidelines (Fig. 4). 
Table 2 Summary of place of sampling, use, elevation, EC, pH and temperature of the water, soil type, and land cover.

\begin{tabular}{|c|c|c|c|c|c|c|c|c|c|c|c|c|}
\hline \multirow{2}{*}{$\begin{array}{l}\text { Varieties } \\
\text { of water }\end{array}$} & \multirow{2}{*}{$\begin{array}{l}\text { Site } \\
\text { No. }\end{array}$} & \multirow[b]{2}{*}{ Place of sampling } & \multicolumn{4}{|c|}{ Use $^{3)}$} & \multirow{2}{*}{$\begin{array}{l}\text { Elevation } \\
\text { (m) }\end{array}$} & \multirow{2}{*}{$\begin{array}{c}\mathrm{EC} \\
(\mathrm{mS} / \mathrm{m})\end{array}$} & \multirow[b]{2}{*}{$\mathrm{pH}$} & \multirow{2}{*}{$\begin{array}{l}\text { Water } \\
\text { temp. } \\
\left({ }^{\circ} \mathrm{C}\right)\end{array}$} & \multirow{2}{*}{$\begin{array}{l}\text { Soil } \\
\text { type }^{4)}\end{array}$} & \multirow{2}{*}{$\begin{array}{l}\text { Land } \\
\text { cover }^{5}\end{array}$} \\
\hline & & & 1 & 2 & 3 & 4 & & & & & & \\
\hline \multirow{6}{*}{$\begin{array}{l}\text { Reservoir } \\
\text { water }\end{array}$} & R1 & Gyobyu reservoir & & & & & 70.061 & 8.63 & 6.39 & 28.3 & $\mathrm{~N}$ & $S$ \\
\hline & $\mathrm{R} 2$ & $\begin{array}{l}\text { Intake of the Gyobyu } \\
\text { reservoir }\end{array}$ & & & & & 72.705 & 8.81 & 6.14 & 29.6 & $\mathrm{~N}$ & $\mathrm{~S}$ \\
\hline & R3 & Phu Gyi reservoir & & & & & 55.401 & 6.50 & 6.17 & 30.0 & G & A \\
\hline & $\mathrm{R} 4$ & Lake Hlawga & & & & & 32.570 & 6.98 & 6.50 & 28.4 & G & A \\
\hline & R5 & Pumping station ${ }^{1)}$ & & & & & 0.847 & 8.23 & 8.15 & 28.8 & G & A \\
\hline & R6 & Pumping station ${ }^{2)}$ & & & & & 0.847 & 8.15 & 7.08 & 28.4 & $\mathrm{G}$ & $\mathrm{A}$ \\
\hline \multirow{9}{*}{$\begin{array}{l}\text { Filtered } \\
\text { water }\end{array}$} & F1 & Pumping station (R5) & o & - & - & - & 0.847 & 7.99 & 7.00 & 29.1 & G & A \\
\hline & $\mathrm{F} 2$ & Pumping station (R6) & $\circ$ & - & - & - & 0.847 & 7.40 & 7.07 & 28.4 & G & A \\
\hline & F3 & Public water & $\circ$ & $\circ$ & ○ & $\circ$ & 21.515 & 5.01 & 7.65 & 27.8 & G & A \\
\hline & F4 & Restaurant 1 & $\circ$ & $\circ$ & $x$ & $x$ & 21.275 & 6.51 & 7.14 & 27.4 & G & A \\
\hline & F5 & Restaurant 2 & $\circ$ & $\circ$ & - & - & 28.725 & 5.21 & 7.45 & 28.0 & G & A \\
\hline & F6 & Hotel & $\circ$ & - & - & - & 6.134 & 13.05 & 6.50 & 27.6 & G & A \\
\hline & F7 & Public water & $\circ$ & - & - & - & 8.057 & 38.10 & 6.33 & 27.8 & G & A \\
\hline & F8 & General store 1 & $\circ$ & - & - & - & 6.134 & 16.03 & 7.19 & 27.8 & G & A \\
\hline & F9 & Water of Hling T Yan reservoir & $\circ$ & - & - & - & 6.855 & 61.80 & 6.00 & 28.7 & $\mathrm{G}$ & A \\
\hline \multirow{18}{*}{$\begin{array}{c}\text { Tube well } \\
\text { water } \\
\text { (deep) }\end{array}$} & $\mathrm{T} 1$ & Private house 1 & o & - & - & - & 24.399 & 26.90 & 5.98 & 27.6 & $\mathrm{~N}$ & $\mathrm{~S}$ \\
\hline & $\mathrm{T} 2$ & Tea shop & $\circ$ & $\times$ & $\circ$ & $x$ & 6.134 & 75.00 & 9.80 & 28.6 & G & A \\
\hline & T3 & Restaurant 1 & $\circ$ & - & - & - & 21.275 & 54.40 & 6.56 & 27.2 & G & A \\
\hline & $\mathrm{T} 4$ & Restaurant 2 & ○ & - & - & - & 28.725 & 17.85 & 7.51 & 28.0 & G & A \\
\hline & T5 & Public & $\circ$ & - & - & - & 30.888 & 10.18 & 6.53 & 27.2 & G & A \\
\hline & T6 & Public & $\circ$ & - & - & - & 30.888 & 9.34 & 5.85 & 27.4 & G & A \\
\hline & $\mathrm{T} 7$ & Public & ○ & $\circ$ & $x$ & $x$ & 15.507 & 31.50 & 5.55 & 27.7 & G & A \\
\hline & $\mathrm{T} 8$ & Public & $\circ$ & $\circ$ & $x$ & $x$ & 29.206 & 11.63 & 5.22 & 27.6 & G & A \\
\hline & T9 & Public & $\circ$ & - & - & - & 7.576 & 35.90 & 8.75 & 27.7 & G & A \\
\hline & $\mathrm{T} 10$ & Public & $\circ$ & ० & ○ & ○ & 5.173 & 9.87 & 7.28 & 27.8 & G & A \\
\hline & $\mathrm{T} 11$ & Public & $\circ$ & ○ & ○ & $x$ & 12.383 & 15.46 & 6.82 & 27.8 & G & A \\
\hline & $\mathrm{T} 12$ & General store 1 & $\circ$ & - & - & - & 6.134 & 467.00 & 5.10 & 27.8 & G & A \\
\hline & $\mathrm{T} 13$ & Public & $\circ$ & $\circ$ & ○ & ○ & 5.894 & 40.00 & 7.25 & 27.6 & G & A \\
\hline & $\mathrm{T} 14$ & Public & $\circ$ & $\circ$ & $\circ$ & $\circ$ & 9.258 & 16.30 & 7.50 & 27.6 & G & A \\
\hline & $\mathrm{T} 15$ & Public & $\circ$ & $\circ$ & $\circ$ & $x$ & -4.681 & 137.70 & 5.49 & 27.4 & G & A \\
\hline & $\mathrm{T} 16$ & Public & $\circ$ & $\circ$ & ○ & $x$ & 1.808 & 17.02 & 7.50 & 26.2 & G & A \\
\hline & $\mathrm{T} 17$ & Public & $\circ$ & $\circ$ & $\circ$ & $\circ$ & 1.808 & 84.60 & 8.20 & 28.9 & G & A \\
\hline & $\mathrm{T} 18$ & Private house 2 & $\circ$ & - & - & - & 6.855 & 34.40 & 5.41 & 28.3 & G & A \\
\hline \multirow{3}{*}{$\begin{array}{l}\text { Dug well } \\
\text { water } \\
\text { (shallow) }\end{array}$} & D1 & Public & o & - & $x$ & $x$ & 17.670 & 28.20 & 5.44 & 29.1 & $\mathrm{G}$ & A \\
\hline & D2 & Public & $\circ$ & ० & ○ & ○ & 7.095 & 35.90 & 8.03 & 26.5 & G & A \\
\hline & D3 & Public & $\circ$ & $\circ$ & $\circ$ & $\circ$ & 25.360 & 45.10 & 5.34 & 28.3 & G & $\mathrm{A}$ \\
\hline $\begin{array}{c}\text { Mineral } \\
\text { water } \\
\text { (bottled } \\
\text { groundwater) } \\
\end{array}$ & M1 & $\begin{array}{l}\text { Water of the } \\
\text { marketing product }\end{array}$ & $x^{6)}$ & o & $\circ$ & $\circ$ & 6.134 & 20.50 & 5.75 & 23.9 & G & A \\
\hline Min. & & & & & & & & 5.01 & 5.10 & 23.9 & & \\
\hline Max. & & & & & & & & 467.00 & 9.80 & 30.0 & & \\
\hline Ave. & & & & & & & & 38.73 & 6.75 & 27.9 & & \\
\hline
\end{tabular}

1) (Lake Hlawga, Phu Gyi reservoir, Gyobyu reservoir, Ngamoyeik reservoir, and rain)

2) (Lake Hlawga and Gyobyu reservoir)

3) Use (1: Domestic water (use except for intake); 2: Cooking water; 3: Drinking water after boiling; 4: Drinking water after not boiling) $\circ$ : suitable; $\times$ : not suitable; -: not clear.

4) Soil Type (N: Nitisol; G: Gleysol) ${ }^{16)}$

5) Land cover (S: Scrubland; A: Agriculture $)^{17)}$

6) Some people in the upper class use "mineral water" for "domestic water.” Ordinary people do not do it because it is expensive. 


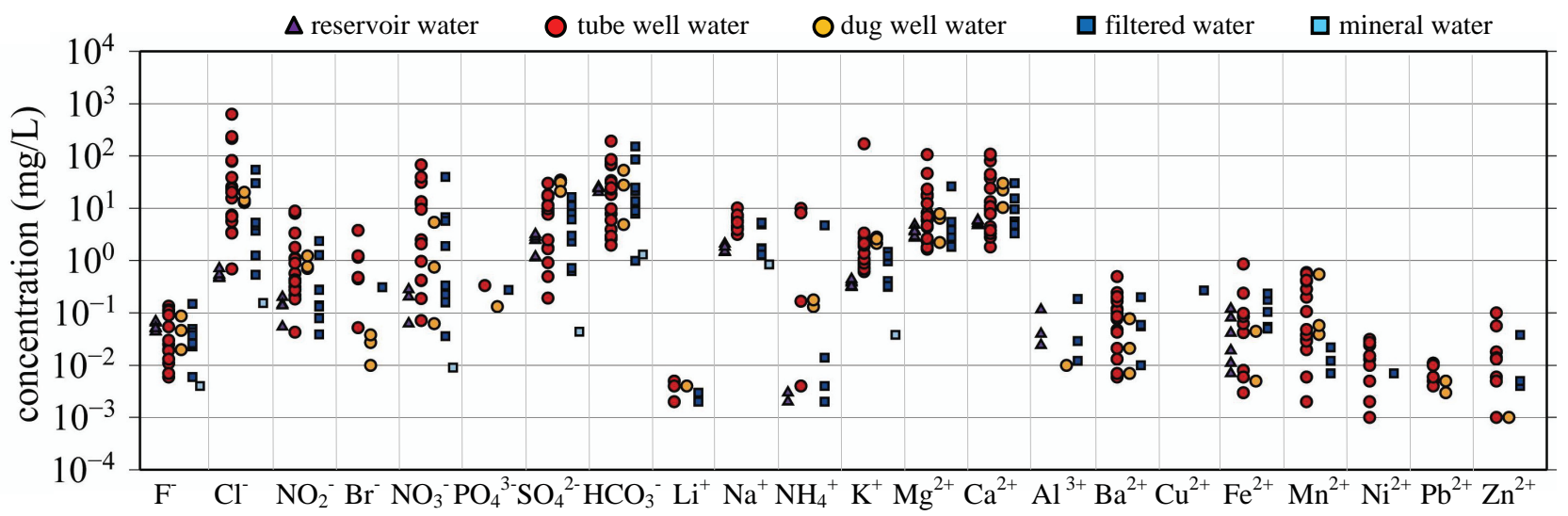

Fig. 3 Water quality: reservoir water (R1-R6), filtered water (F1-F9), tube well water (T1-T18), dug well water (D1-D3), mineral water (bottled groundwater) (M1). Value of "not detected" is not shown in this figure.
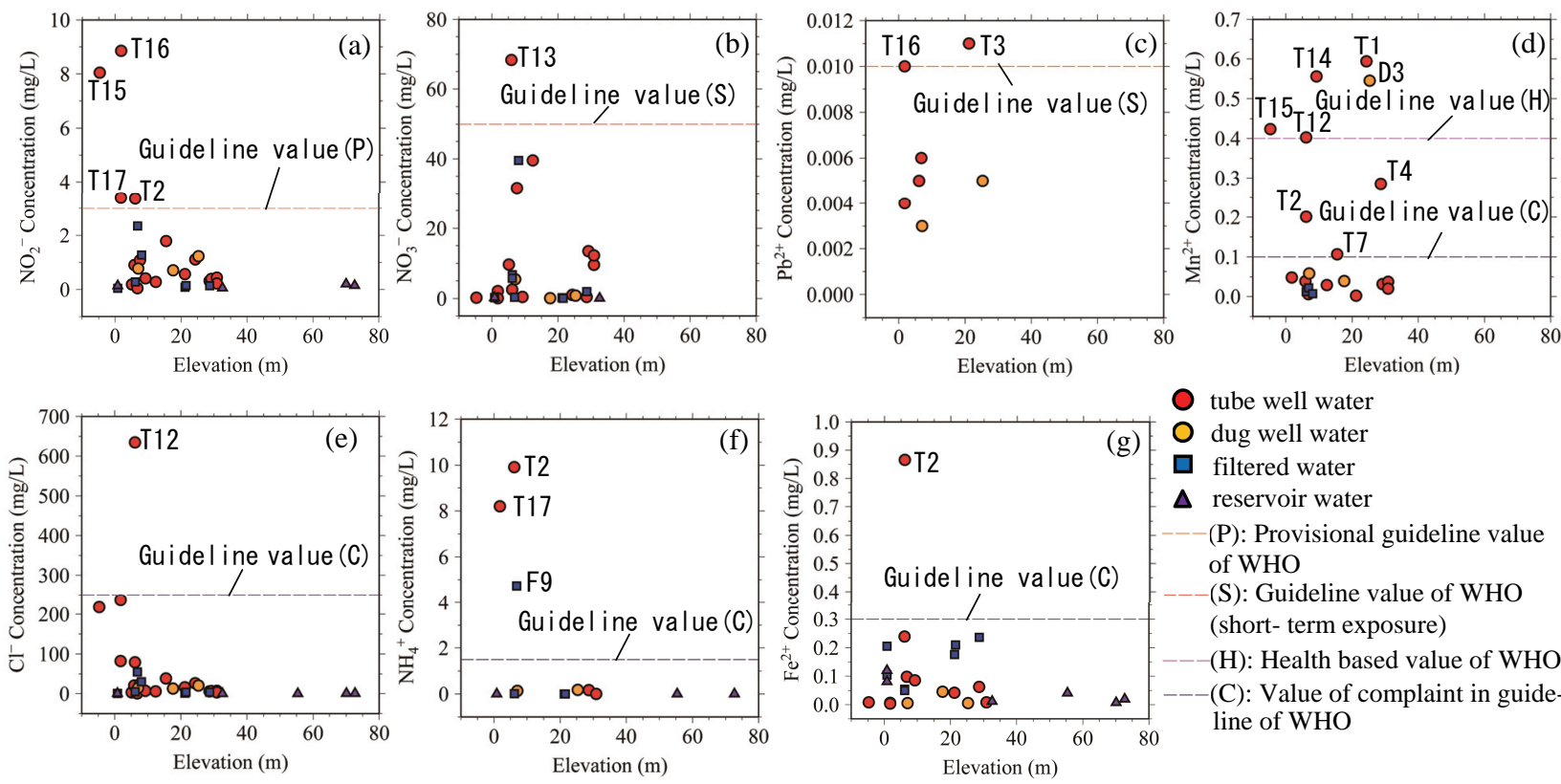

O tube well water

O dug well water

$\square$ filtered water

$\Delta$ reservoir water

$-(\mathrm{P})$ : Provisional guideline value of WHO

(S): Guideline value of WHO (short- term exposure)

(H): Health based value of WHO

(C): Value of complaint in guideline of WHO

Fig.4 Correlation between elevation and concentration ((a) $\mathrm{NO}_{2}^{-}$, (b) $\mathrm{NO}_{3}^{-}$, (c) $\mathrm{Pb}^{2+}$, (d) $\mathrm{Mn}^{2+}$, (e) $\mathrm{Cl}^{-}$, (f) $\mathrm{NH}_{4}^{+}$, (g) $\mathrm{Fe}^{2+}$ ). (P) : Provisional guideline value of WHO; (S) : Guideline value of WHO (short-term exposure); (C) : Complaint guideline value of WHO (acceptability aspects: Taste, odor, and appearance); $(\mathrm{H})$ : Health-based value of WHO. Value of "not detected " is not shown in this figure. (Elevation of GPS data: Altimeter: Accuracy; +/-10feet (3.048m), resolution; $1 \mathrm{ft} .(0.3048 \mathrm{~m})$ )

\section{(2) Relation of elevation and water quality}

The elevations of the reservoir (R1-R3) and lake (R4) are high: 32.57 to $72.705 \mathrm{~m}$. The elevation of the pumping station (R5 and R6) is low at $0.847 \mathrm{~m}$. The elevations of filtered waters (F1-F9) are $0.847-28.73 \mathrm{~m}$. The elevations of tube well waters (D1-D3) are $-4.681-30.888 \mathrm{~m}$. The elevations of dug well waters are $7.095-25.360 \mathrm{~m}$. As a trend, the values of electric conductivity were high at low elevations. The waters located at elevations less than about $10 \mathrm{~m}$ were more likely to be polluted (Table 2).

Fig. 4 shows the correlations among elevation and concentration ((a) $\mathrm{NO}_{2}{ }^{-}$, (b) $\mathrm{NO}_{3}{ }^{-}$, (c) $\mathrm{Pb}^{2+}$, (d) $\mathrm{Mn}^{2+}$, (e) $\mathrm{Cl}^{-}$, (f) $\mathrm{NH}_{4}^{+}$, (g) $\mathrm{Fe}^{2+}$ ). Some waters located at elevation less than about 30m exceeded the guideline values of WHO for drinking water. The details are discussed in Section (3).

\section{(3) Water quality and WHO guidelines ${ }^{18)}$}

The chemical components beyond the guideline values of WHO for drinking water were $\mathrm{NO}_{2}^{-}, \mathrm{NO}_{3}^{-}$, $\mathrm{Pb}^{2+}$, and $\mathrm{Mn}^{2+}$. The chemical components beyond the values of complaint (the values of comfort) were $\mathrm{Mn}^{2+}, \mathrm{Cl}^{-}, \mathrm{NH}_{4}^{+}$, and $\mathrm{Fe}^{2+}$. 
Table 3 Chemically derived contaminants and WHO guidelines for drinking water quality ${ }^{18), 20)-24), 26), 27) . ~}$

\begin{tabular}{|c|c|c|}
\hline Chemical contaminant & Guideline value & Treatment performance and additional comments \\
\hline $\mathrm{NO}_{2}^{-}$ & 3mg/L (P) & $0.1 \mathrm{mg} / \mathrm{l}$ should be achievable using chlorination (to form nitrate). \\
\hline $\mathrm{NO}_{3}^{-}$ & 50mg/L (S) & $\begin{array}{l}\text { - } 5 \mathrm{mg} / \mathrm{l} \text { or lower should be achievable using biological denitrification (surface } \\
\text { waters) or ion exchange (groundwaters). }\end{array}$ \\
\hline $\mathrm{Pb}^{2+}$ & $0.01 \mathrm{mg} / \mathrm{L}(\mathrm{S})$ & $\begin{array}{l}\text { - Not a raw water contaminant; treatment not applicable. } \\
\text { - Lead is exceptional compared with other chemical hazards, in that most lead } \\
\text { in drinking water arises from plumbing in buildings, and the remedy consists } \\
\text { principally of removing plumbing and fittings containing lead. This requires } \\
\text { much time and money, and it is recognized that not all water will meet the } \\
\text { guideline values immediately. Meanwhile, all other practical measures to } \\
\text { reduce total exposure to lead, including corrosion control, should be imple- } \\
\text { mented. }\end{array}$ \\
\hline $\mathrm{Mn}^{2+}$ & $\begin{array}{l}0.4 \mathrm{mg} / \mathrm{L}(\mathrm{H}) \\
0.1 \mathrm{mg} / \mathrm{L}(\mathrm{C})\end{array}$ & $\begin{array}{l}\text { - Slow filtration. } \\
\text { flocculating setting and filtration treatment method using sodium hypo- } \\
\text { chlorite and the manganese sand. }\end{array}$ \\
\hline $\mathrm{Cl}^{-}$ & 250mg/L (C) & - \\
\hline $\mathrm{NH}_{4}^{+}$ & $1.5 \mathrm{mg} / \mathrm{L}(\mathrm{C})$ & - \\
\hline $\mathrm{Fe}^{2+}$ & $0.3 \mathrm{mg} / \mathrm{L}(\mathrm{C})$ & - \\
\hline
\end{tabular}

(P) : Provisional guideline value of WHO; (S) : Guideline value of WHO (short-term exposure); (C) : Complaint guideline value of WHO (acceptability aspects: Taste, odor, and appearance); $(\mathrm{H})$ : Health-based value of WHO.

Table 3 summarizes the chemically derived contaminants and the WHO guidelines for drinking water quality.

\section{a) Chemical hazards in drinking water $\left(\mathrm{NO}_{2}^{-}\right.$, $\mathrm{NO}_{3}{ }^{-}, \mathrm{Pb}^{2+}$, and $\mathrm{Mn}^{2+}$ )}

Nitrate and nitrite are naturally occurring ions that are part of the nitrogen cycle. The nitrate ion $\left(\mathrm{NO}_{3}{ }^{-}\right)$ is the stable form of combined nitrogen for oxygenated systems. Although chemically unreactive, it can be reduced by microbial action. The nitrite ion $\left(\mathrm{NO}_{2}{ }^{-}\right)$contains nitrogen in a relatively unstable oxidation state. Chemical and biological processes can further reduce nitrite to various compounds or oxidize it to nitrate ${ }^{20)}$.

$\mathrm{NO}_{2}{ }^{-}$concentrations of samples are shown in Fig. 4(a). Guideline value is $3 \mathrm{mg} / \mathrm{L}$ as nitrite ion to protect against methaemoglobinaemia in bottle-fed infants (short-term exposure) ${ }^{18)}$. The $\mathrm{NO}_{2}{ }^{-}$concentrations of tube well waters (T2, T15, T16, and T17) were greater than the guideline values. These are the waters that are unsuitable for drinking in their present form. People used the tube well waters (T2, T15, and T16) for drinking after boiling, and did not use them for drinking directly. Users of tube well water (T17) use it for drinking.

$\mathrm{NO}_{3}{ }^{-}$concentrations of samples are shown in Fig. 4(b). Guideline value is $50 \mathrm{mg} / \mathrm{L}$ as nitrate ion to protect against methaemoglobinaemia in bottle-fed infants (short-term exposure) ${ }^{18)}$. The $\mathrm{NO}_{3}{ }^{-}$concen- tration of tube well water (T13) was higher than the guideline value. Users of tube well water (T13) use it for drinking.

Lead $\left(\mathrm{Pb}^{2+}\right)$ is rarely present in tap water as a result of its dissolution from natural sources; rather, its presence is primarily from corrosive water effects on household plumbing systems containing lead in pipes, solder, fittings, or the service connections to homes. The amount of lead dissolved from the plumbing system depends on several factors, including $\mathrm{pH}$, temperature, water hardness, and standing time of the water, with soft, acidic water being the most plumbosolvent $\mathrm{t}^{21)}$.

$\mathrm{Pb}^{2+}$ concentrations of samples are shown in Fig. 4(c). The guideline value of lead is $0.01 \mathrm{mg} / \mathrm{L}(10$ $\mu \mathrm{g} / \mathrm{L})^{21)}$. The $\mathrm{Pb}^{2+}$ concentrations of tube well waters (T3 and T16) were higher than the guideline values.

Manganese $\left(\mathrm{Mn}^{2+}\right)$ occurs naturally in many surface water and groundwater sources, particularly in anaerobic or low oxidation conditions, and this is the most important source for drinking water. Manganese occurs naturally in many food sources, and the greatest exposure to manganese is usually from food. The reason for not establishing a guideline value (0.4 $\mathrm{mg} / \mathrm{L}$ ) is not a health concern at levels found in drinking water ${ }^{22), 23)}$.

In this study, $\mathrm{Mn}^{2+}$ concentrations of five samples (T1, T12, T14, T15, and D3) were higher than 0.4 mg/L (Fig. 4(d)). 
b) Acceptability aspects: Taste, odor, and appearance $\left(\mathrm{Mn}^{2+}, \mathrm{Cl}^{-}, \mathrm{NH}_{4}{ }^{+}\right.$and $\mathrm{Fe}^{2+}$ )

At levels exceeding $0.1 \mathrm{mg} / \mathrm{L}$, manganese in water supplies causes an undesirable taste in beverages and stains sanitary ware and laundry. The presence of manganese in drinking water, like that of iron, may lead to the accumulation of deposits in the distribution system ${ }^{22), 23)} \cdot \mathrm{Mn}^{+2}$ concentrations of tube well waters (T1, T2, T4, T7, T12, T14, T15, and D3) were higher than $0.1 \mathrm{mg} / \mathrm{L}$ (Fig. 4(d)).

One tube well water (T12) was greater than 250 $\mathrm{mg} / \mathrm{L}^{24)}$ in $\mathrm{Cl}^{-}$(Fig. 4(e)). Water with high $\mathrm{Cl}^{-}$concentration is not suitable for drinking water or domestic water because such waters have a bad taste and are not good for health. Reportedly 38\% of people complain about relation between skin diseases and use of unclean water, especially salty water ${ }^{25}$. During the dry season, seawater intrudes into the delta and the flows are contained within the banks of the channels except in the case of the saline inter-tidal mangrove swamps near the ocean ${ }^{17)}$. The users of tube well (T12) can use both the water of tube well and filtered water (F8) properly for their own purposes.

The threshold odor concentration of ammonia $\left(\mathrm{NH}_{4}{ }^{+}\right)$at alkaline $\mathrm{pH}$ is approximately $1.5 \mathrm{mg} / \mathrm{L}$, and a taste threshold of $35 \mathrm{mg} / \mathrm{L}$ has been proposed. Ammonia is not of direct relevance to health at these levels, and no health-based guideline value has been proposed ${ }^{26)}$. $\mathrm{NH}_{4}{ }^{+}$concentrations of tube well waters (T2, T17, and F9) were higher than $1.5 \mathrm{mg} / \mathrm{L}$ (Fig. 4(f)). The filtered water (F9) was not from the Gyobyu reservoir but from the Hling $\mathrm{T}$ Yan reservoir. For these cases, some kind of prompt remedy such as chlorination is expected. People in Myanmar reported that the water of the Gyobyu reservoir was good.

At levels above $0.3 \mathrm{mg} / \mathrm{L}$, iron stains laundry and plumbing fixtures. There is usually no noticeable taste at iron concentrations below $0.3 \mathrm{mg} / \mathrm{L}$, although turbidity and color may develop. No health-based guideline value is proposed for iron ${ }^{27}$. $\mathrm{Fe}^{2+}$ concentration of tube well water (T2) was higher than 0.3 $\mathrm{mg} / \mathrm{L}$ of the WHO complaint value (Fig. 4(g)).

\section{(4) Classification by water quality}

The concentrations of major ionic constituents of water samples are shown in the Piper trilinear diagram $^{28), 29)}$ to ascertain the water type. The cation and anion facies are classified in terms of major ion percentage and water types, according to the domain in which they occur on the diagram segments ${ }^{30}$. Numerous studies have used this method ${ }^{31)-33)}$. 5.

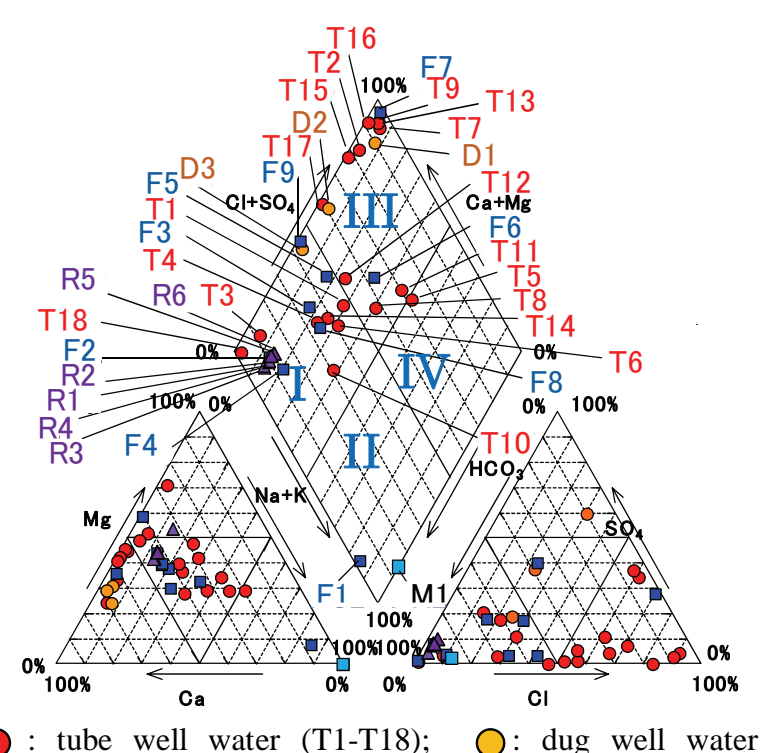

(D1-D3); $\square$ : filtered water (F1-F9); $\Delta$ : reservoir water (R1-R6); $\square$ : mineral water (bottled groundwater) (M1) .

Fig.5 Piper diagram:

I: $\mathrm{Ca}\left(\mathrm{HCO}_{3}\right)_{2}$ and $\mathrm{Mg}\left(\mathrm{HCO}_{3}\right)_{2}$ waters: typical of "shallow, fresh groundwater" and "river water."

II: $\mathrm{NaHCO}_{3}$ waters: typical of "deeper fresh ground waters influenced by ion exchange.”

III: $\mathrm{CaCl}_{2}$ and $\mathrm{CaSO}_{4}$ waters: typical of "spring water," "fossil water," "gypsum groundwater," and "mine drain age."

IV: $\mathrm{NaCl}$ and $\mathrm{Na}_{2} \mathrm{SO}_{4}$ waters: typical of "sea water," "spring water," "marine, deep, and ancient groundwater."

The waters classified into " $\mathrm{Ca}\left(\mathrm{HCO}_{3}\right)_{2}$ and $\mathrm{Mg}\left(\mathrm{HCO}_{3}\right)_{2}$ " type (Type I) are almost all "filtered water" samples (F2, F3, F4, F5, F8, F9), "reservoir water" samples (R1-R6), tube well water samples (T1, T3, T4, T6, T10, T14, T18) and dug well water sample (D3). They correspond mainly to "shallow, fresh groundwater (circulating groundwater),"and "river water" types.

The waters classified into " $\mathrm{NaHCO}_{3}$ " type (Type II) are the rest of "filtered water" samples (F1) and "mineral water" (M1). They correspond mainly to "deeper fresh groundwater influenced by ion exchange" types.

The water classified into " $\mathrm{NaCl}$ and $\mathrm{Na}_{2} \mathrm{SO}_{4}$ " type (Type IV) is tube well water (T8). They correspond mainly to "sea water," "spring water," and "marine, deep, and ancient groundwater" types.

The waters classified into " $\mathrm{CaCl}_{2}$ and $\mathrm{CaSO}_{4}$ " type (Type III) are tube well water waters (T2, T7, T8, T9, T11, T12, T13, T15, T16, and T17), dug well waters (D1 and D2) and filtered water (F6 and F7). They correspond mainly to "spring water," "fossil water," "gypsum groundwater,” and "mine drainage.” 
Table 4 Direct distance from pumping station to tap of filtered water, and tube well/dug well samples near the tap.

\begin{tabular}{ccccc}
\hline $\begin{array}{l}\text { Site } \\
\text { No. }\end{array}$ & Elevation (m) & $\begin{array}{c}\text { Water } \\
\text { Type }\end{array}$ & Direct distance $(\mathrm{m})^{2)}$ & $\begin{array}{c}\text { Site No. of tube well/dug well samples } \\
\text { near the tap }\end{array}$ \\
\hline F3 & 21.515 & I & 3.75 & T3, $\underline{\mathbf{T} 4}$ \\
\hline F4 & 21.275 & I & 4.25 & T3,T4 \\
\hline F5 & 28.725 & I & 2.45 & T3, $\underline{\mathbf{T} 4}$ \\
\hline F6 & 6.134 & III & 7.55 & $\underline{\mathbf{T 1 2}}, \mathrm{T} 13, \mathrm{~T} 15$ \\
\hline F7 & 8.057 & III & 6.45 & T8, $\underline{\mathbf{T 9}}, \mathrm{T} 10, \mathrm{~T} 11$ \\
\hline F8 & 6.134 & I & 6.50 & $\underline{\mathbf{T 1 2}}, \mathrm{T} 13, \mathrm{~T} 15$ \\
\hline
\end{tabular}

Bold and underline sample: Sample Nos. of wells of which water is supposed to intrude into the tap of filtered water 1) Site No. of tap of filtered water, 2) Direct distance from pumping station to the tap of filtered water.

The high concentration of $\mathrm{Cl}^{-}$and the sampling locations in the delta near the sea suggested that they would be in Type IV and derived from sea water. At first we had supposed that the high $\mathrm{Cl}^{-}$concentration was caused by the intrusion of sea water into aquifer which was the source for well waters. However, they were plotted in Type III. They turned out to be classified into Type III containing high percentage of $\left(\mathrm{Ca}^{2+}\right.$ and $\left.\mathrm{Mg}^{2+}\right)$ and $\left(\mathrm{Cl}^{-}\right.$and $\left.\mathrm{SO}_{4}{ }^{2-}\right)$ instead of Type IV containing high percentage of $\left(\mathrm{Na}^{+}\right.$and $\left.\mathrm{K}^{+}\right)$and $\left(\mathrm{Cl}^{-}\right.$and $\left.\mathrm{SO}_{4}{ }^{2-}\right)$. It suggested that minerals in rock would dissolve into water in large amount ${ }^{34)}$. Therefore, we supposed that the origin of the water would be fossil water, that is, sea water contained in layers for long period.

Table 4 shows the direct distance from pumping station to tap of filtered water, and tube well/dug well samples near the tap. For the taps of which water type was Type I, the direct distances to the taps of F3, F4, $\mathrm{F} 5$, and $\mathrm{F} 8$, were $3.75 \mathrm{~m}, 4.25 \mathrm{~m}, 2.45 \mathrm{~m}$, and $6.50 \mathrm{~m}$, respectively. Their elevations were $21.515 \mathrm{~m}$, $21.275 \mathrm{~m}, 28.725 \mathrm{~m}$, and $6.134 \mathrm{~m}$, respectively. For the taps of which water type was Type III, the direct distances to the taps of F6 and F7 were $7.55 \mathrm{~m}$ and $6.45 \mathrm{~m}$ with elevations of $6.134 \mathrm{~m}$ and $8.057 \mathrm{~m}$, respectively. It was observed that the water type of tap with longer direct distance and lower elevation has a tendency to be classified into Type III. Normally the water type at the tap would be unchanged from the type at the pumping station without mixture or intrusion of other water types. Thus we examined the possibility of intrusion.

F4 was classified into Type I and plotted on almost the same positions of pumping station water (F2) and reservoir water (R1-R6) in Fig.5. It meant that their water qualities were similar. Since F4 was plotted away from T3 and T4 in Fig.5, it was suggested that
F4 was not influenced by T3 and T4, although their locations were geographically close as shown in Fig.1. It indicated that the pipeline from the pumping station to F4 tap would not be intruded and the water quality would be maintained.

F3 and F5 were also classified into Type I similar to pumping station water (F2) and reservoir water (R1-R6), but they were plotted away from F2 and R1-R6 in Fig.5. It suggested that their water qualities were a little different from F2 and R1-R6. Fig.1 showed that F3 and F5 were located near T3 and T4, and Fig. 5 showed that F3 and F4 were plotted near T4. This suggested that F3 and F4 would be influenced by $\mathrm{T} 4$.

F8 were classified into Type I similar to pumping station water (F2) and reservoir water (R1-R6), but F8 was plotted away from R1-R6 in Fig.5. It suggested that its water quality was a little different from F2 and R1-R6. Fig.1 showed that F8 was located near T2, T13, and T15, and Fig.5 showed that T12 was the closest to F8. This suggested that F8 might be influenced by $\mathrm{T} 12$.

F6 was classified into Type III, and Fig.1 showed that F6 was located near T12, T13, and T15. Since Fig.5 showed that T12 was the closest to F6, it suggested that F6 might be influenced by T12.

F7 was also classified into Type III, and Fig.1 showed that F7 was located near T8, T9, T10, and T11. Since Fig.5 showed that T9 was very close to F7, it suggested that F7 would be influenced by T9.

The above discussion suggests that the intrusion pathways of contaminants exist on the routes from the pumping station to the taps (F3, F5-F8).

\section{(5) Treatment performance and practical con- siderations}

Table 3 shows the treatment performance rec- 
Table 5 Livestock Farming in Yangon City (2005, 2008, and 2009).

\begin{tabular}{cccccccc}
\hline Sr No. & Varieties & 2005 & $\%$ & 2008 & $\%$ & 2010 & $\%$ \\
\hline 1 & Cattle & 7,560 & 3.74 & 1,500 & 0.77 & 4,600 & 1.84 \\
2 & Buffalo & 2,050 & 1.01 & 0 & 0.00 & 2,580 & 1.03 \\
3 & Pig & 13,710 & 6.78 & 17,900 & 9.14 & 42,800 & 17.1 \\
4 & Goat & 3,640 & 1.80 & 4500 & 2.30 & 0 & 0.00 \\
5 & Fowl & 134,690 & 66.58 & 152,000 & 77.59 & 151,000 & 60.34 \\
6 & Duck & 40,650 & 20.09 & 20,000 & 10.21 & 49,270 & 19.69 \\
\hline & Total & 192,690 & 95.25 & 194,400 & 99.23 & 243,070 & 97.13 \\
\hline
\end{tabular}

(State of Peace and Development Council of Yangon City. 2012) ${ }^{19)}$

ommended by the WHO guidelines for the chemical contaminants beyond the guideline values. Regarding $\mathrm{NO}_{3}{ }^{-}$, the following practical considerations are recommended:

i) With regard to piped supplies where nitrate is present, the first potential approach to treatment of drinking-water supplies, if source substitution is not feasible, is to dilute the contaminated water with a low-nitrate source (e.g., high-elevation reservoirs).

ii) Well water was more contaminated by soil, excreta from animal husbandry, and artificial pollution, than filtered water was. In Myanmar, the raising of draught animals, i.e., cattle and buffaloes, is rather limited, reflecting the small area of farmland. Among the cattle and buffaloes, some are raised for milk, which is in great demand. Pigs, chickens, and ducks are raised mostly for home consumption, although a few households raise them at too small a commercial scale to satisfy local market needs. The numbers of these livestock are presented in Table 5. Disposal methods of excreta are such that some people from outer urban areas freely dispose of them on the ground; YCDC (Yangon City Development Committee) comes to collect it by car from inner urban areas (hearing report from State Peace and Development Council of Yangon City) ${ }^{19)}$.

The most appropriate means of controlling nitrate concentrations, particularly for groundwater, is the prevention of contamination. This may take the form of appropriate management of agricultural practices, the careful siting of pit latrines and septic tanks, sewer leakage control, as well as management of fertilizer and manure application, and storage of animal manures. It may also take the form of denitrification of wastewater effluents.

\section{CONCLUSION}

In most areas of Myanmar, groundwater and river water are used for both drinking and domestic water. The hygiene environment and the health damage caused by polluted water have become social prob- lems, thus, immediate measures are demanded. Although early research ${ }^{6)}$ had already reported that coliform and E. Coli were detected in all the survey areas, little information on chemical hazards has been reported. From the viewpoint of the effects of chemical components on water quality, we measured the concentrations such as $\mathrm{NO}_{3}{ }^{-}$, and compared them with WHO guidelines. Then we discussed the measures for improvement.

1) Some tube well waters, dug well waters, and filtered waters were estimated as contaminated and unsuitable for drinking, cooking, domestic use, and healthy life.

2) Waters located at elevation less than about $10 \mathrm{~m}$ were more likely to be polluted.

3) The chemical components beyond the drinking water guideline values of WHO for health were $\mathrm{NO}_{2}^{-}, \mathrm{NO}_{3}^{-}, \mathrm{Pb}^{2+}$, and $\mathrm{Mn}^{2+}$. The components beyond the values of comfort of WHO were $\mathrm{Mn}^{2+}$, $\mathrm{Cl}^{-}, \mathrm{NH}_{4}^{+}$, and $\mathrm{Fe}^{2+}$.

4) The water type analysis by Piper diagram suggested that intrusion pathways of contaminants included the routes from pumping stations to taps. For the taps with longer direct distances from the pumping station and at lower elevations, there were several cases in which the tube well water geographically close to the tap intruded into the tap of filtered water.

5) If source substitution is not feasible, the first potential approach to treatment of drinking water supplies is to dilute the contaminated water with a low-contaminated source (e.g., high-elevation reservoirs).

6) It is most desirable to improve the systems as follows: (a) piping routes from reservoir to user places should be maintained as sanitary and clean, and (b) tube well water systems should be improved to prevent the intrusion of contaminants.

ACKNOWLEDGMENTS: This work was partly supported by research funds from Mie University and Grants-in-Aid for Scientific Research from the Japan Society for the Promotion of Science (No. 
21401003). The authors are grateful to Dr. Kihira and Prof. Kato of the Iga Research Institute of Mie University, and to Miss Takagi of Mie University for their help in the ICP analyses.

\section{REFERENCES}

1) WHO : Burden of disease and cost-effectiveness estimates, 2004. http://www.who.int/water_sanitation_health/diseases /burden/en/index.html, Last access November 9, 2012.

2) WHO : Children: environmental health: Water, sanitation and hygiene Data by country. http://apps.who.int/gho/data/ view.main.36200, Last access November 9, 2012.

3) Comly, H. H. : Cyanosis in infants caused by nitrates in well water, Journal of the American Medical Association, Vol. 129, pp. 112-116, 1945, DOI:10.1001/jama.1945.0286036 0014004.

4) Ridder, W. E. and Oehme, F. W. : Nitrates as an environmental, animal, and human hazard, Clinical Toxicology, Vol. 7, pp. 145-159, 1974, DOI:10.3109/15563657408987 991.

5) Abe, Y. : Infectious disease of the wet season, Embassy of Japan in Myanmar, http://www.mm.emb-japan.go.jp /profile /japanese/pdf/Padauk_Uki.pdf, Last access October 10, 2012 (In Japanese).

6) Akaishi, F., Satake, M. and Otaki, M. : Water usage in Myanmar, Journal of Human Environmental Engineering, Vol. 6, No. 2, pp. 212-215, 2004 (In Japanese).

7) Akaishi, F., Otaki, M., Tominaga, N. and Satake, M. : Water quality and usage at Kachin State in Myanmar hilly area, Journal of Human Environmental Engineering, Vol. 7, No. 1, pp. 96-99, 2005 (In Japanese).

8) Akaishi, F., Satake, M., Otaki, M. and Tominaga, N. : Surface water quality and information about the environment surrounding Inle Lake in Myanmar, Limnology, Vol. 7, No. 1, pp. 57-62, 2006, DOI:10.1007/s10201-006-0165 $-1$.

9) Takahashi, K. : Life abroad and water in Myanmer, Japan Overseas Medical Fund Japan Overseas Medical Fund, 1998, http://www.jomf.or.jp/include/disp_text.php?type= n200\&file=1999020110, Last access October 20, 2012 (In Japanese).

10) Ministry of Foreign Affairs of Japan: Information of Myanmar by the medical affairs official of the government establishments abroad, 2013, http://www.mofa.go.jp/mofaj/ toko/medi/asia/myanmar.html, Last access February 9. 2013 (In Japanese).

11) Union of Myanmar (Department of Meteorology and Hydrology, Forest Department, Relief and Resettlement Department, Irrigation Department and Fire Services Department), Myanmar Engineering Society, Myanmar Geosciences Society, Myanmar Information Management Unit and Asian Disaster Preparedness Center : Hazard profile of Myanmar, pp. 48-55, 2009.

12) Senda, M., Kuzuha, Y., Kay, T. H., Miyaoka, K. and Haruyama, S. : Research on Water Environment in Myanmar, Proceedings of 2011 Annual Conference of the Japan Society of Civil Engineers, September 7-9, 2011 Ehime, Japan, 66, VII-20, VII39-40, DVD, 2011 (In Japanese).

13) Suido Sangyo Shinbun Corporation : World water service circumstances, In Water service yearbook, Suido Sangyo Shinbun Corporation, Tokyo, pp. 162-163, 2012 (In Japanese).

14) Department of Meteorology and Hydrology, Yangon, Myanmar, 2013, http://www.dmh.gov.mm/, Last access January 10, 2013 (In Myanmar and English).
15) Garmin: GPSMAP60CSx owner’s manual, pp.91, 2007.

16) Food and Agriculture Organization of the United Nations : FAO/NRL from Harmonized World Soil Database (HWSD) - FAO, Geographical distribution of 10 dominant soil types in Myanmar, http://www.fao.org/nr/myanmar/SoilMap _Myanmar_300dpi.jpg, Last access December 10, 2012.

17) Irrigation Department, Ministry of Agriculture and Irrigation, Myanmar, 2013, http://id.moai.gov.mm/, Last access January 10, 2013 (In Myanmar and English).

18) WHO : Guidelines for drinking-water quality, fourth edition, pp. 1-541, 2011. http://whqlibdoc.who.int/ publications/2011/9789241548151_eng.pdf

19) Yangon City Development Committee (YCDC), 2012. http://www.yangoncity.com.mm/. Last access January 9, 2013 (In Myanmar and English).

20) ICAIR Life Systems, Inc. : Drinking water criteria document on nitrate/nitrite, Washington, DC, United States Environmental Protection Agency, Office of Drinking Water, 1987.

21) $\mathrm{FAO} / \mathrm{WHO}$ : Evaluation of certain food additives and contaminants, WHO, Lead in drinking-water, pp. 1-19, 2011. http://www.who.int/water_sanitation_health/dwq/ chemicals/lead.pdf.

22) IPCS (1999) Manganese and its compounds. Geneva, WHO, International Programme on Chemical Safety (Concise International Chemical Assessment Document 12). http://www.bvsde.paho.org/bvsacd/who/ipcs.pdf.

23) WHO : Manganese in drinking-water, pp. 1-21, 2011. http://www.who.int/water_sanitation_health/dwq/chemical s/manganese.pdf.

24) WHO : Chloride in drinking-water, pp.1-4, 2003. http:// www.who.int/water_sanitation_health/dwq/chloride.pdf.

25) Ministry of Health, Myanmar : http://www.moh.gov.mm/, 2013, Last access January 9, 2013 (In Myanmar and English).

26) WHO : Ammonia in drinking-water, pp. 1-4, 2003. http:// www.who.int/water_sanitation_health/dwq/ammonia.pdf.

27) WHO : Iron in drinking-water, pp.1-4, 2003.http://www. who.int/water_sanitation_health/dwq/chemicals/iron.pdf.

28) Piper, A. M. : A graphic procedure in the geochemical interpretation of water analyses, American Geophysical Union, Vol. 24, No. 6, pp. 914-923, 1944.

29) Piper, A. M. : A graphic procedure in the geochemical interpretation of water analyses, Trans. U.S. Geol. Survey Groundwater Note, No. 12, Washington, 1953.

30) Back, W. : Hydrochemical facies and ground-water flow patterns in northern part of Atlantic Coastal Plain, U.S. Geological Survey Professional Paper, Vol. 498-A, United States Government Printing Office, Washington D.C., pp. 42, 1966.

31) Gmati, S., Tase, N., Tsujimura, M. and Tosaki, Y. : Aquifers interaction in the southwestern foot Mt. Fuji, Japan, examined through hydrochemistry and statistical analyses, Hydrological Research Letters, Vol. 5, pp. 58-63, 2011. DOI:10.3178/HRL.5.58.

32) Phillip, M. : Geochemistry, Geo-Heat Center Bulletin, Vol. 13, No. 1, pp. 8-12, 1991.

33) Ramkumar, T., Venkatramanan, S., Mary, I. A., Tamilselvi, M. and Ramesh, G. : Hydrogeochemical quality of groundwater in Vedraniyam town, TamilNadu, India, Research Journal of Environmental and Earth Sciences, Vol. 2, No. 1, pp. 44-48, 2010.

34) Kodansha Academy EST : Encyclopedia of science and technology, pp. 324-326, 1977 (In Japanese).

(Received March 25, 2014) 